\title{
Pretreatment with pentoxifylline attenuates lung injury induced by intestinal ischemia/reperfusion in rats $^{1}$
}

\author{
Pré-tratamento com pentoxifilina atenua a lesão pulmonar induzida por \\ isquemia/reperfusão intestinal em ratos
}

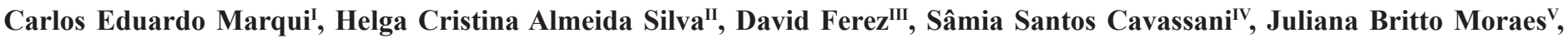

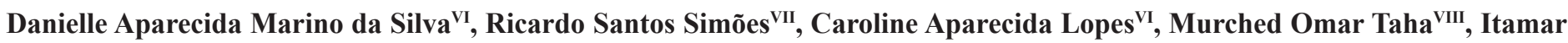
Souza Oliveira-Júnior ${ }^{\mathrm{IX}}$

IFellow PhD degree, Division of Anesthesiology, Pain and Intensive Therapy, UNIFESP, Sao Paulo-SP, Brazil. Executing the work and writing the manuscript.

IIFull Professor, Division of Anesthesiology, Pain and Intensive Therapy, UNIFESP, Sao Paulo-SP, Brazil. Data analysis and writing the manuscript.

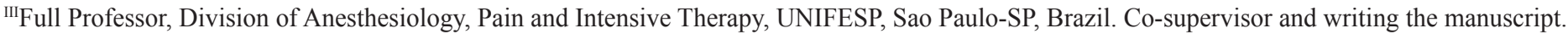

${ }^{\text {IV }}$ Master in Science, Division of Anesthesiology, Pain and Intensive Therapy, UNIFESP, Sao Paulo-SP, Brazil. Animal anesthesia and handling and analysis of the cytokine determinations.

${ }^{v}$ Graduate student, Scientific Initiation, Division of Anesthesiology, Pain and Intensive Therapy, UNIFESP, Sao Paulo-SP, Brazil. Analysis of the determination of myeloperoxidase activity.

${ }^{\mathrm{VI}}$ Graduate student, Scientific Initiation, Division of Anesthesiology, Pain and Intensive Therapy, UNIFESP, Sao Paulo-SP, Brazil. Analysis of the determination of total proteins content, malondialdehyde and histological analysis.

${ }^{V I I}$ Fellow PhD degree, Department of Morphology and Genetics, Histology Division, UNIFESP, Sao Paulo-SP, Brazil. Histological analysis.

${ }^{V I I I}$ Associate Professor, Department of Surgery, UNIFESP, Sao Paulo-SP, Brazil. Data analysis and Writing the manuscript.

${ }^{\mathrm{IX}}$ Associate Professor, Division of Anesthesiology, Pain and Intensive Therapy, UNIFESP, Sao Paulo-SP, Brazil. Supervisor and writing the manuscript.
\end{abstract}

\section{ABSTRACT}

PURPOSE: To investigate the protective effect of pentoxifylline against the lung injury observed after intestinal ischemia (I) followed by a period of reperfusion $(\mathrm{R})$.

METHODS: Twenty-eight male Wistar rats were equally divided into 4 experimental groups and operated under ketamine-xylazine anesthesia. (1) Sham: falsely-operated animals; (2) SS+IR: intestinal ischemia was accomplished by clipping the superior mesenteric artery during 60 minutes, with an administration of a standard volume of saline solution (SS) $5 \mathrm{~min}$ before the end of the ischemia period; the clip was then releases or a 120-min period of reperfusion; (3) I+PTX+R: ischemia as above, PTX was administered (25 mg/ $\mathrm{kg}$ ) and the gut reperfused as above; (4) PTX+I+PTX+R: Five minutes before arterial occlusion PTX was administered; the superior mesenteric artery was then clipped for 60 minutes. After 55-min ischemia, an additional dosis of PTX was administered; the clip was removed for reperfusion as above. At the 60th min of reperfusion a third dosis of PTX was administered.

RESULTS: PTX markedly attenuated lung injury as manifested by significant decreases (all $\mathrm{P}<0.001$ as compared with the SS+IR group) of pulmonary wet/dry tissue weight ratio, total protein content, myeloperoxidase activity and tumor necrosis factor-alpha. Moreover, it was apparent that in the group PTX $+\mathrm{I}+\mathrm{PTX}+\mathrm{R}$ the improvements have been even more significant.

CONCLUSION: PTX exerted a protective effect on the lung from the injuries caused by intestinal ischemia/reperfusion.

Keywords: Lung Injury. Ischemia. Reperfusion Injury. Oxidative Stress. Pentoxifylline. Rats.

\section{RESUMO}

OBJETIVO: Avaliar os efeitos protetores da pentoxifilina (PTX) na lesão pulmonar observada após isquemia (I) seguida de reperfusão (R) intestinal.

MÉTODOS: Vinte e oito ratos machos foram divididos aleatoriamente em quatro grupos experimentais e operados sobre anestesia quetamina-xilazina. (1) Sham: animais falsamente operados; (2) SS+IR: isquemia intestinal realizada pelo clampeamento da artéria 
mesentérica superior durante 60 minutos, com a administração de solução salina (SS) 5 minutos antes do período de isquemia, após a retirada do clamp houve a reperfusão por mais 120 minutos; (3) I+PTX+R: isquemia como mencionado anteriormente seguida da administração de PTX ( $25 \mathrm{mg} / \mathrm{Kg}$ ) 5 minutos antes do final da isquemia (60 minutos) seguida de reperfusão por mais 120 minutos; (4) PTX+I+PTX+R: 5 minutos antes da isquemia foi administrado PTX, após 55 minutos de isquemia foi administrado outra dose de PTX e a reperfusão mantida por mais 120 minutos, sendo que aos 60 minutos da reperfusão outra dose de PTX foi administrada.

RESULTADOS: A pentoxifilina reduziu os marcadores de lesão pulmonar (proteínas totais, malondialdeído, atividade da mieloperoxidase e fator de necrose tumoral) quando comparada com o grupo não tratado $(\mathrm{P}<0.001)$, contudo esta redução foi mais significante no grupo $\mathrm{PTX}+\mathrm{I}+\mathrm{PTX}+\mathrm{R}$.

CONCLUSÃO: A pentoxifilina exerce efeito protetor no pulmão no trauma causado por isquemia/reperfusão intestinal. Descritores: Lesão Pulmonar. Isquemia. Traumatismo por Reperfusão. Estresse Oxidativo. Pentoxifilina. Ratos.

\section{Introduction}

Regardless the cause, an intestinal ischemia insult is a serious and growing clinical problem, with an unacceptable mortality rate over $60 \%{ }^{1}$.

Intestinal ischemia and reperfusion (I/R) leads to an acute local inflammatory response, resulting in increased microvascular permeability. Intestinal $\mathrm{I} / \mathrm{R}$ is a common medical event associated with both clinical and experimental distant organ injury. In particular, the lung tissue appears to be susceptible to injury resulting from systemic oxidative stress and inflammatory mediators activation. Despite decades of research in this area, I/R injury remains a clinically challenging problem ${ }^{2-7}$ and particularly susceptible to the damaging effects of increased neutrophil activation following intestinal $\mathrm{I} / \mathrm{R}^{8}$. Consequently, many cases of intestinal I/R progress into shock, multiple organ failure, and death $^{9,10}$.

Acute lung injury (ALI) and acute respiratory distress syndrome (ARDS) is a consequence of host response to a variety of direct or indirect stimuli leading to pulmonary inflammation. Many of the clinical conditions associated with the development of acute respiratory failure include periods of ischemia ${ }^{11-13}$.

Pentoxifylline (PTX), a methylxanthine derivative known for many years for its haemorheological properties, has proven to be a potent inhibitor of tumor necrosis factor (TNF) production $^{14}$. It has been suggested that PTX can enhance the chemotactic response of neutrophils, but may inhibit phagocytosis and the superoxide production by neutrophils and monocytes ${ }^{15}$. It has also been shown that this drug has beneficial effects in patients with lung ischemia/reperfusion injury ${ }^{16}$. The potential local effects are important for acute lung injury manifestation by inflammatory mediators that are blood- and lymph-borne ${ }^{\mathrm{x}, \mathrm{y}, \mathrm{z}}$, and oxygen-free radical activations ${ }^{17,18}$.

Based on these literature data, herein we put forward the hypothesis that the pre-treatment with PTX may reduce lung injury in rats submitted to intestinal ischemia/reperfusion. For this purpose we used an animal model of intestinal $\mathrm{I} / \mathrm{R}$ in which a superior mesenteric artery occlusion-reperfusion simulates the I/R injury that may occur in clinical situations, and investigated the effects of PTX on the systemic (pulmonary) repercussions of this insult.

\section{Methods}

\section{Surgical procedure and experimental design}

All animal procedures were approved by the Institutional Research Committee at Federal University of Sao Paulo (1551/09). It was designed as an experimental, randomized, controlled study with blind assessment to the outcome.

Twenty-eight adult male Wistar rats $(n=7$ for every group; body weights were 270 to $300 \mathrm{~g}$ ) were fasted overnight with free access to water. Anesthesia was induced by a single intraperitoneal injection of ketamine $(80 \mathrm{mg} / \mathrm{kg})$ plus xylazine $(10$ $\mathrm{mg} / \mathrm{kg}$ ), and the abdomen and groin were shaved and washed with $10 \%$ povidone iodine. A PE-50 tubing catheter was inserted in the femoral vein for saline or PTX (Pentox ${ }^{\circledR}$, Farmasa, SP, Brazil) solution infusion. PTX was suspended in Ringer lactate solution to a concentration of $25 \mathrm{mg} / \mathrm{kg}$ as described previously ${ }^{19-26}$. Upon a 2-cm midline laparotomy, the superior mesenteric artery was isolated at its origin and occluded with a Bulldog ${ }^{\circledR}$ atraumatic microvascular clamp (Harvard Apparatus, MA, USA) during $60 \mathrm{~min}$. Mesenteric ischemia was confirmed by cessation of the mesenteric pulsations and a palish appearance of the intestines. At the end of ischemia period the clamp was released and reperfusion (during $120 \mathrm{~min}$ ) was confirmed by restoration of the pulsations and the normal gut color. The animals were randomly assigned to one of four groups, as follows. Rats of the Sham (falsely operated) group were anesthetized and subjected only to laparotomy and visceral manipulation. Group SS+I/R: animals subjected to $\mathrm{I} / \mathrm{R}$ and injected with $0.1 \mathrm{ml}$ of saline solution (SS) 5 minutes before 
reperfusion. Group $\mathrm{I}+\mathrm{PTX}+\mathrm{R}$ : ischemia procedure as above and, 5 minutes before reperfusion, PTX was administered $(25 \mathrm{mg} / \mathrm{kg}$ in $0.1 \mathrm{ml}$ ). Group $\mathrm{PTX}+\mathrm{I}+\mathrm{PTX}+\mathrm{R}$ : pre-treatment with PTX 5 minutes before ischemia, then another PTX dosis 5 minutes before the end of ischemia and a final dosis of PTX at the 60th minute of the reperfusion period. Body temperature was maintained to $37^{\circ} \mathrm{C}$ $\left(37 \pm 0.6^{\circ} \mathrm{C}\right)$ with a heating pad.

At the end of experiment the animals were euthanized ( $\mathrm{T}$ 61 Euthanasia Solution $^{\circledR}$, Schering-Plough, SP, Brazil).

\section{Bronchoalveolar lavage (BAL) fluid for protein assay}

Upon thoracotomy, bronchoalveolar lavages (BALs) were taken by flushing three times the right lung with sterile saline via an intratracheal cannula, using a Miniplus $3^{\circledR}$ peristaltic pump (Gilson, WI, USA). The recovery rate was $>85 \%$. The collected BALs were centrifuged at $300 \times \mathrm{g}$ for $4 \mathrm{~min}$ at $4^{\circ} \mathrm{C}$ and the supernatant was used for protein determination by the method of Lowry et $a l .{ }^{27}$.

The upper lobe of right lungs was removed and homogenized (Thorton, INPC, SP, Brazil) in PBS for further myeloperoxidase (MPO) activity, thiobarbituric reactive substances-malondialdehyde (TBARS-MDA) and tumor necrosis factor-alpha (TNF- $\alpha)$ measurements.

\section{Determination of lipid derived oxidation products}

The thiobarbituric acid reactive substancemalondiadehyde (TBARS-MDA) content of lung tissue was determined using the method described by Ohkawa et al. ${ }^{28}$.

\section{Myeloperoxidase (MPO) activity}

Homogenates were centrifuged at $15,000 \times \mathrm{g}$ for $10 \mathrm{~min}$ at $4{ }^{\circ} \mathrm{C}$. A $100 \mathrm{~mL}$-aliquot of supernatant was mixed with 900 $\mathrm{mL}$ of $50 \mathrm{mmol} \cdot \mathrm{L}^{-1}$ phosphate buffer $(\mathrm{pH}=6.0)$ containing 0.167 $\mathrm{mg} \cdot \mathrm{mL}^{-1}$ of $o$-dianisidine dihydrochloride and $0.0005 \%$ hydrogen peroxide. One unit of peroxidase activity is taken as the amount of enzyme decomposing $1 \mathrm{mmol}$ of hydrogen peroxide per minute at $25^{\circ} \mathrm{C}$. Decomposition of hydrogen peroxide was calculated from the oxidation of $o$-dianisidine by using an absorption coefficient of $11.3 \mathrm{mmol} \cdot \mathrm{L}^{-1} \cdot \mathrm{cm}^{-1}$ at $460 \mathrm{~nm}^{29}$.

\section{Cytokine assay}

Tissue TNF- $\alpha$ content was measured in lung homogenates using commercially available, rat-specific enzyme immunoassay (ELISA) kits (Quantikine, R\&D Systems, MN, USA). Results were expressed as $\mathrm{pg} / \mathrm{mL}$. Absorbance was determined at $450 \mathrm{~nm}$ using a microplate reader (Bio-Tek Instruments, VT, USA).

\section{Morphology}

The middle lobe of the right lung was fixed in buffered formalin. After embedding in paraffin, 4- $\mu \mathrm{m}$ sections of the tissues were stained with hematoxylin-eosin (HE) for light microscopy coupled to a video camera (Axiolab Standart 2.0 and AxionCam, Zeiss, Jena, Germany, respectively). The slides were evaluated blindly by an independent consultant histopathologist.

\section{Wet to dry tissue weight ratio}

The lower lobe of the right lung was isolated and immediately weighed (wet weight) before being dried for $48 \mathrm{~h}$ at $80^{\circ} \mathrm{C}$ and weighed again (dry weight). The wet/dry weight ratio was then calculated.

\section{Statistical analysis}

Statistical analyses were carried out with a SPSS 11.0 statistical software (SPSS Inc. Software, IL, USA). Data were analyzed by 1-way analysis of variance (ANOVA) with a LSD post-hoc test to determine comparisons and differences between groups, respectively. All values are expressed as mean \pm standard deviation with $P<0.05$ being considered significant.

\section{Results}

No deaths were recorded throughout the experiment. The protein content in BALs (Figure 1) increased in the group SS+IR $(62.71 \pm 4.61 \mathrm{mg} / \mathrm{mL})$, and decreased in the groups treated with PTX (I+PTX+R: $50.14 \pm 3.93 \mathrm{mg} / \mathrm{mL}$; PTX+I+PTX+R: $36.28 \pm$ $3.35 \mathrm{mg} / \mathrm{mL})$. 


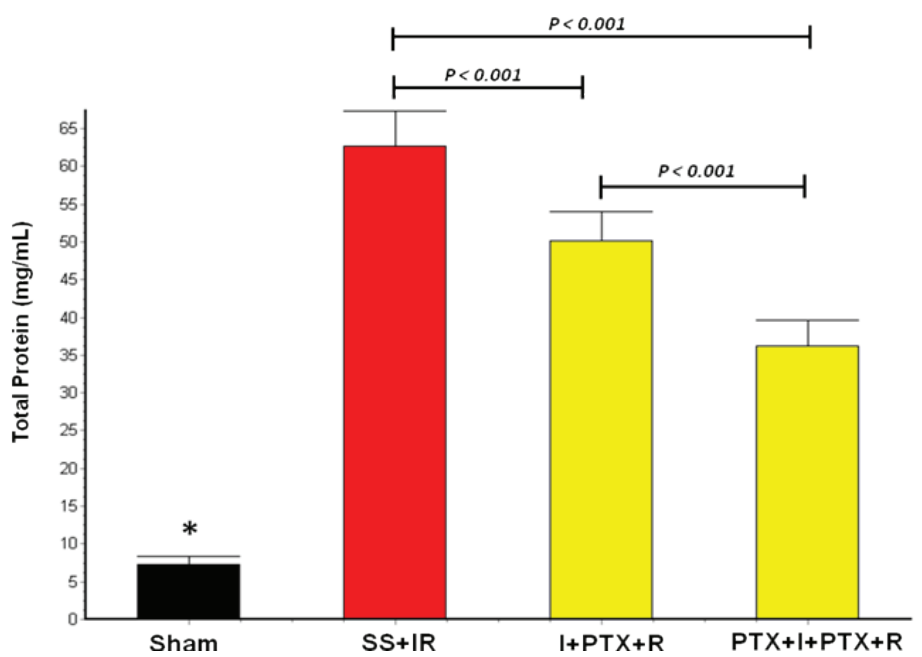

FIGURE 1 - Protein content in BALs from rats falsely operated (Sham) or subjected to mesenteric artery clamping for intestinal ischemia during $60 \mathrm{~min}$, followed by clamp release for a 120-min period of reperfusion (IR). Control IR rats were treated i.v. with $0.1 \mathrm{~mL}$ saline solution (group SS+IR). Other IR rats were treated with pentoxifylline (PTX): group I + PTX $+\mathrm{R}$ received i.v. $25 \mathrm{mg} / \mathrm{kg}$ of PTX $5 \mathrm{~min}$ before starting the reperfusion period; the group $\mathrm{PTX}+\mathrm{I}+\mathrm{PTX}+\mathrm{R}$ received i.v. three doses of PTX: one 5 min before ischemia, a second one $5 \mathrm{~min}$ before starting reperfusion, and a third one at the 60th min of reperfusion. Data are mean \pm SD. ${ }^{*} P<0.001$ compared with all other groups.

The lipid peroxidation (TBARS-MDA; Figure 2) was significantly higher in the control IR group (SS+IR: $62.14 \pm 4.22$ $\mathrm{nmol} / \mathrm{mg}$ protein) as compared with the $\mathrm{I}+\mathrm{PTX}+\mathrm{R}(52.28 \pm 2.63$ $\mathrm{nmol} / \mathrm{mg}$ protein $)$ and the $\mathrm{PTX}+\mathrm{I}+\mathrm{PTX}+\mathrm{R}(43.42 \pm 1.27 \mathrm{nmol} / \mathrm{mg}$ protein) groups.

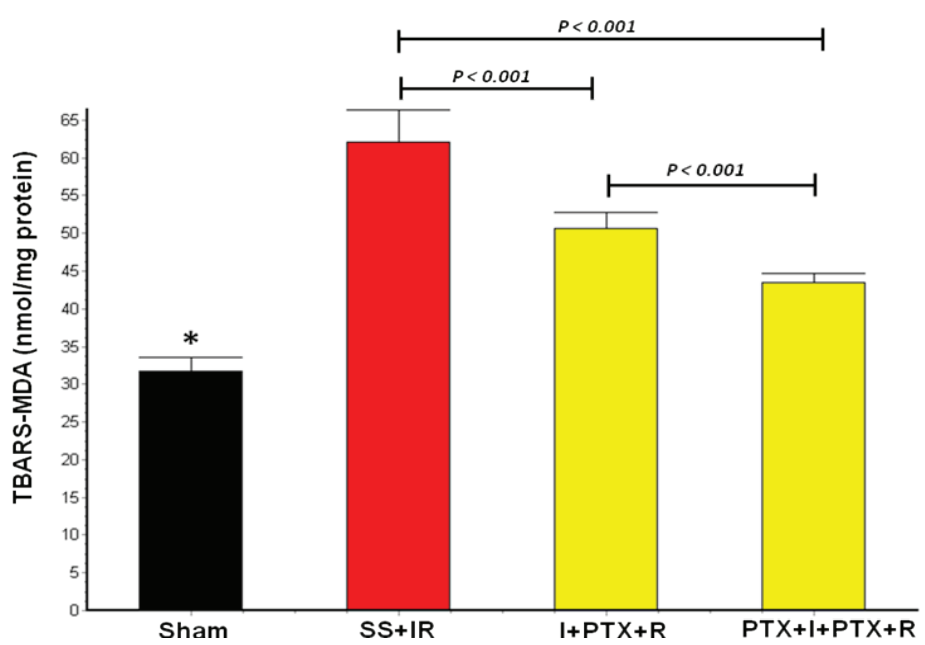

FIGURE 2 - Effect of pentoxifylline treatment on lipid-derived oxidation products as determined by the levels of thiobarbituric acid reactive substance-malondiadehyde (TBARS-MDA) in rat lung homogenates. Groups are as in the legend to Figure 1. Data are mean \pm SD. ${ }^{*} P<0.001$ regarding all other groups.

Myeloperoxidase activity (MPO; Figure 3) was lower in the group $\mathrm{PTX}+\mathrm{I}+\mathrm{PTX}+\mathrm{R}(30.71 \pm 2.81 \mathrm{U} / \mathrm{mg}$ protein when compared with $\mathrm{SS}+\mathrm{IR}(47.43 \pm 2.15 \mathrm{U} / \mathrm{mg}$ protein $)$ and $\mathrm{I}+\mathrm{PTX}+\mathrm{R}$ $(40.43 \pm 3.21 \mathrm{U} / \mathrm{mg}$ protein $)$.

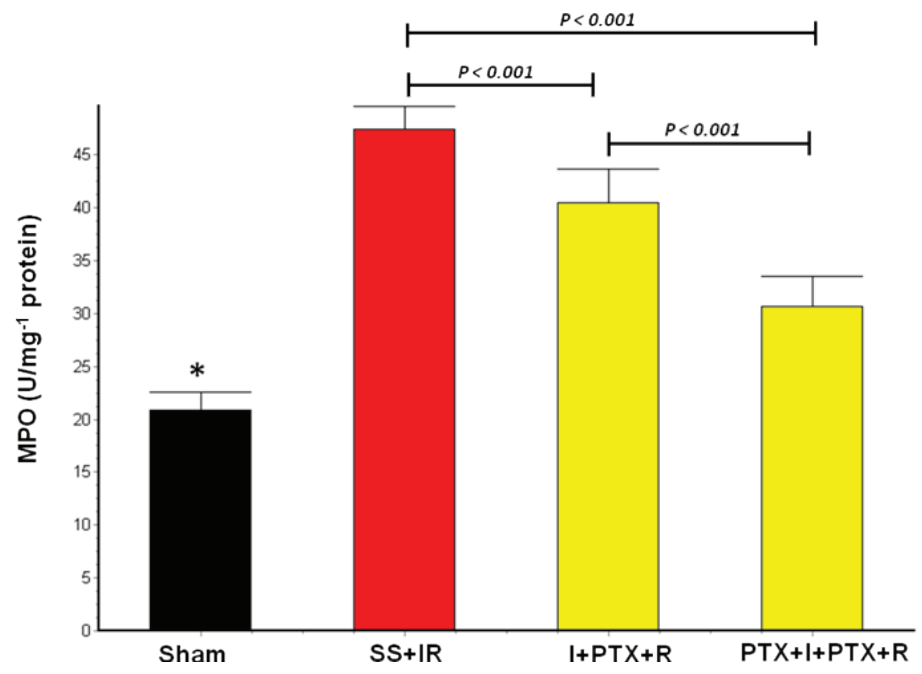

FIGURE 3 - Effect of pentoxifylline treatment on the myeloperoxidase (MPO) activity in rat lung homogenates. Groups are as in the legend to Figure 1. Data are mean $\pm \mathrm{SD}$. ${ }^{*} P<0.001$ regarding all other groups.

The levels of TNF-alpha (Figure 4) in lung homogenates were higher in all groups when compared with those of the Sham group. The has been an increase of TNF-alpha levels in the group $\mathrm{SS}+\mathrm{IR}(67.14 \pm 6.82 \rho \mathrm{g} / \mathrm{mL})$, and a reduction in PTX-treated groups, I+PTX+R $(55.86 \pm 2.27 \mathrm{pg} / \mathrm{mL})$ and $\mathrm{PTX}+\mathrm{I}+\mathrm{PTX}+\mathrm{R}$ $(47.57 \pm 2.64 \mathrm{pg} / \mathrm{mL})$.

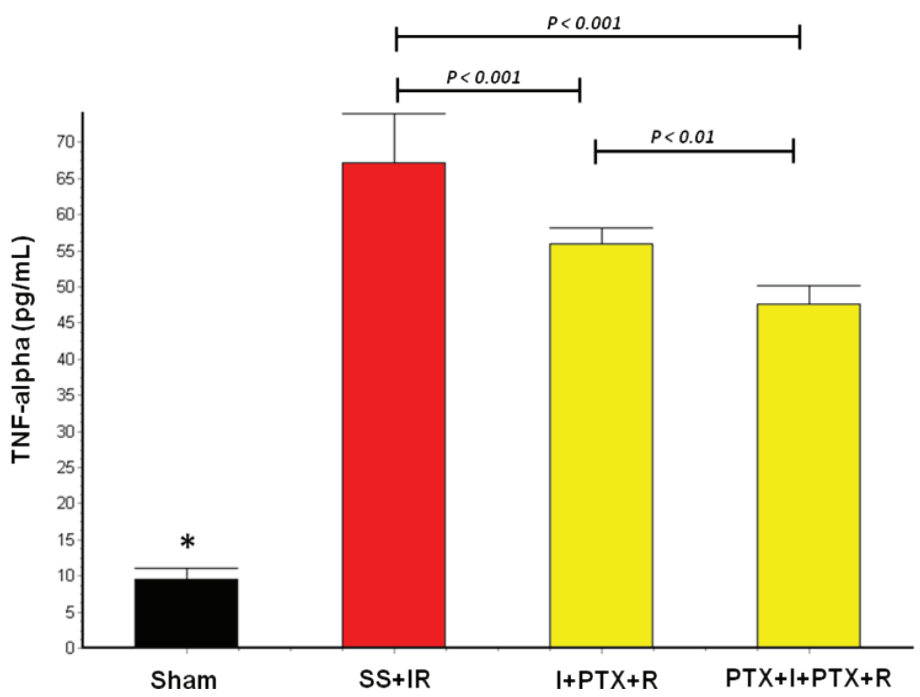

FIGURE 4 - Effect of pentoxifylline treatment on the tumor necrosis factor (TNF)-alpha content in rat lung homogenates. Groups are as in the legend to Figure 1. Data are mean $\pm \mathrm{SD} .{ }^{*} P<0.001$ regarding all other groups.

Figure 5 shows typical lung histological features from 
both normal and sham-operated [Sham] rats. Lungs from the group saline solution plus ischemia-reperfusion [SS+IR] showed severe changes. As seen, there was a marked leukocyte (neutrophil) infiltration; the alveolar, perivascular, and capillary dilation lead to alveolar capillaries wall thickening. These parameters in the groups $\mathrm{I}+\mathrm{PTX}+\mathrm{R}$ and $\mathrm{PTX}+\mathrm{I}+\mathrm{PTX}+\mathrm{R}$ were all significantly improved.

Lung weights (W/D ratios) in Sham group (3.62 \pm 0.31$)$ were not altered after the 120-min experimental period. The SS+IR group had a significantly higher ratio $(6.16 \pm 0.26)$ than that in the Sham group. This parameter significantly decreased in the groups $\mathrm{I}+\mathrm{PTX}+\mathrm{R}(5.34 \pm 0.25)$ and $\mathrm{PTX}+\mathrm{I}+\mathrm{PTX}+\mathrm{R}(4.5 \pm 0.35)$ when compared with SS+IR.

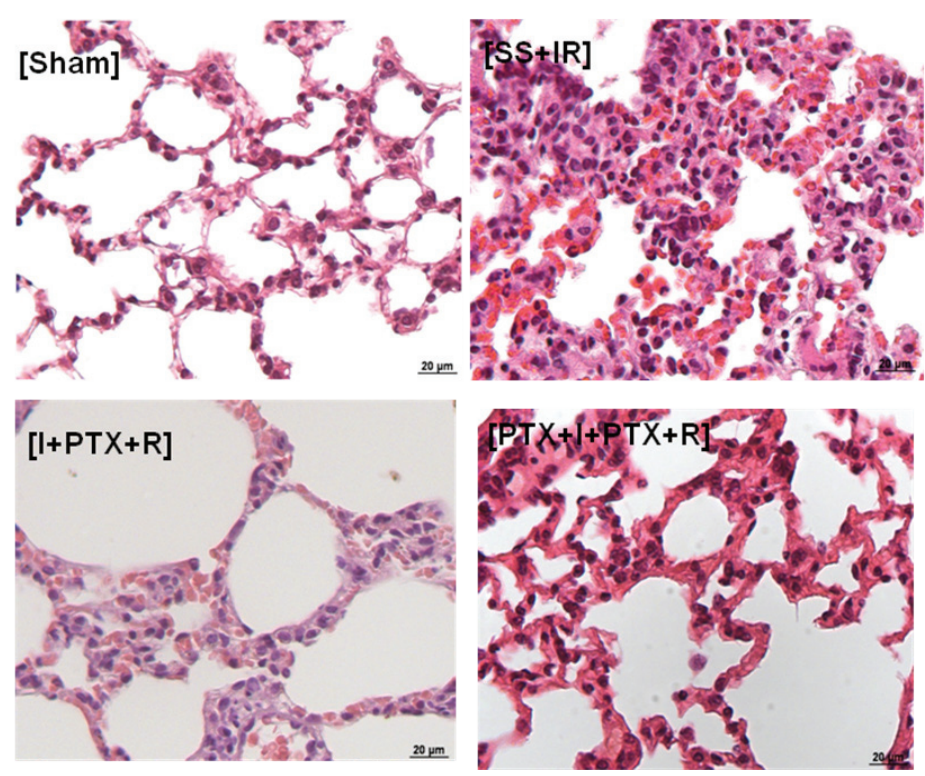

FIGURE 5 - Histological lung sections of lungs from sham-operated rats [Sham] show a normal pulmonary architecture. In the group SS+IR it can be seen massive alveolar congestion and neutrophil infiltration. In the groups treated with pentoxifylline, $([\mathrm{I}+\mathrm{PTX}+\mathrm{R}]$ and $[\mathrm{PTX}+\mathrm{I}+\mathrm{PTX}+\mathrm{R}])$ the interstitial congestion was minimal, and the leukocyte (neutrophil) infiltration was strongly reduced. Hematoxylin and eosin staining. Scale bar: $20 \mu \mathrm{m}$. (H.E - 200X).

\section{Discussion}

Our current study showed that I/R caused acute lung injury, as reflected by increases in protein concentration, MDA levels and MPO activity in the lung homogenates, W/D ratio, and TNF-alpha levels in lung homogenate and gene expression in lung tissue.

Multiple factors contribute to I/R-induced inflammatory responses, including complement activation, reactive oxygen species (ROS), cytokines, and chemokines. The pulmonary vascular endothelium is a barrier to prevent fluids and proteins into the interstitium of the lung. These inflammatory mediators have been demonstrated to disrupt or injure the endothelial lining and lead to increased pulmonary vascular permeability which is the major feature of acute lung injury ${ }^{30}$. Neutrophil sequestration and transmigration in the lung play an important role in the pathogenesis of ALI/ARDS. Many investigators have demonstrated that $I / R$ lung injury is neutrophil-dependent ${ }^{31-33}$.

Our results corroborate with these results by demonstrate the augments of protein concentration, TBARS-MDA and MOP activity in the homogenate in lung tissue of group SS+IR and reduced by PTX administration (groups $\mathrm{I}+\mathrm{PTX}+\mathrm{R}$ and $\mathrm{PTX}+\mathrm{I}+\mathrm{PTX}+\mathrm{R})$

Intestinal I/R injury causes local damage as well as remote organ injury and dysfunction. The pathophysiology of I/R injury is complex, the induction of a systemic proinflammatory cytokine response is believed to play a major role, and TNF-alpha is among the most important contributors ${ }^{34,35}$. In a elegant study conducted by Cámara-Lemarroy et al. $^{36}$, showed that intestinal I/R-induced lung injury was associated with elevated levels of circulating serum TNF-alpha, and the treatment of one dose of PTX reduced the intensity of injury and the tissue edema. Lung cytokine levels are actually determined by the amount of cytokines released from a variety of cell populations, including alveolar macrophages, endothelial cells, and epithelial cells, and these multiple sources mean that reduced neutrophil infiltration of the lungs may not directly translate to a decreased level of cytokines in the lung ${ }^{37-39}$. Our studies corroborated with these authors and expanded of the result. In our study, the TNF-alpha levels in homogenate lung tissue were higher in the saline-treated group (SS+IR) and reduced in the group $\mathrm{I}+\mathrm{PTX}+\mathrm{R}$, but the decreased was more significant in the group treated with three doses of pentoxifylline $(\mathrm{PTX}+\mathrm{I}+\mathrm{PTX}+\mathrm{R})$.

Morphological examination indicate the severe impact in the lung tissue submitted to I/R non-treated, by other hand the treatment with PTX reduced the lung damage, especially in the group treated with three doses of PTX.

Our study demonstrated that pentoxifylline had preventive effects and therapeutic potential in I/R-induced lung injury, but our results must be considered carefully. The clinical relevance of this manuscript refers to the previous use of pentoxifylline in situations requiring procedures ischemia with reperfusion to reduce or prevent distant organs damage. Therefore, the long-term effect of pentoxifylline warrants further investigation.

In conclusion, our study showed that pentoxifylline decreased lung edema, ameliorated lung histological change, reduced the production of inflammatory mediators, and neutrophils in intestinal I/R-induced lung injury. Pentoxifylline has been given 
safely in previous clinical studies. Therefore, the administration of pentoxifylline may be a useful prophylactic or adjunct drug therapy for intestinal I/R-induced lung injury.

\section{References}

1. Schoenberg MH, Beger HG. Oxygen radicals in intestinal ischemia and reperfusion. Chem Biol Interact. 1990;76:141-61.

2. Köksoy C, Kuzu MA, Kuzu I, Ergun H, Gurhan I. Role of tumour necrosis factor in lung injury caused by intestinal ischaemiareperfusion. Br J Surg. 2001;88:464-8.

3. Souza DG, Cara DC, Cassali GD, Coutinho SF, Silveira MR, Andrade SP, Poole SP, Teixeira MM. Effects of the PAF receptor antagonist UK74505 on local and remote reperfusion injuries following ischaemia of the superior mesenteric artery in the rat. $\mathrm{Br} \mathrm{J}$ Pharmacol. 2000;131:1800-8.

4. Hassoun HT, Kone BC, Mercer DW, Moody FG, Weisbrodt NW, Moore FA. Post-injury multiple organ failure: the role of the gut. Shock. 2001;15:1-10.

5. Pierro A, Eaton S. Intestinal ischemia reperfusion injury and multisystem organ failure. Semin Pediatr Surg. 2004;13:11-7.

6. Mallick IH, Yang W, Winslet MC, Seifalian AM. Ischemiareperfusion injury of the intestine and protective strategies against injury. Dig Dis Sci. 2004;49:1359-77.

7. Aytekin FO, Tekin K, Kabay B, Erdem E, Guney Y, Firat P, Sungurtekin U, Kaya SO, Ozden A. Antithrombin III attenuates pulmonary tissue injury caused by mesenteric ischemia-reperfusion. Am J Surg. 2005;189:161-6.

8. Kalia N, Brown NJ, Wood RF, Hopkinson K, Fairburn B, Pockley AG. Effects of intestinal ischemia-reperfusion injury on rat peripheral blood neutrophil activation. Dig Dis Sci. 2003;48:16774.

9. Kozar RA, Holcomb JB, Hassoun HT, Macaitis J, DeSoignie R, Moore FA. Superior mesenteric artery occlusion models shockinduced gut ischemia-reperfusion. J Surg Res. 2004;116:145-50.

10. Stallion A, Kou TD, Latifi SQ, Miller KA, Dahms BB, Dudgeon $\mathrm{DL}$, Levine AD. Ischemia/reperfusion: a clinically relevant model of intestinal injury yielding systemic inflammation. J Pediatr Surg. 2005;40:470-7.

11. Steinberg J, Halter J, Schiller H, Gatto L, Nieman G. The development of acute respiratory distress syndrome after gut ischemia/reperfusion injury followed by fecal peritonitis in pigs: a clinically relevant model. Shock. 2005;23:129-37.

12. Ward DT, Lawson SA, Gallagher CM, Conner WC, Shea-Donohue T. Sustained nitric oxide production via 1 -arginine administration ameliorates effects of intestinal ischemia-reperfusion. J Surg Res. 2000;89:13-9.

13. Grotz MR, Deitch EA, Ding J, Xu D, Huang Q, Regel G. Intestinal cytokine response after gut ischemia: Role of gut barrier failure. Ann Surg. 1999;229:478-86.

14. Bessler H, Gilgal R, Djaldetti M, Zahavi I. Effect of pentoxifylline on the phagocytic activity, cAMP levels, and superoxide anion production by monocytes and polymorphonuclear cells. J Leukocyte Biol. 1986;40:747-54.

15. Mandel GL. ARDS, neutrophils and pentoxifylline. Am Rev Respir Dis. 1988;138:1103-5.

16. Chapelier A, Reignier J, Mazmanian M, Detruit H, Dartevelle P, Parquin F, Cerrina J, Le Roy Ladurie F, Hervé P. Pentoxifylline and lung ischemia-reperfusion injury: Application to lung transplantation. Universite Paris-Sud Lung Transplant Group. J Cardiovasc Pharmacol. 1995;25:S130-3.
17. Seekamp A, Warren JS, Remick DG, Till GO, Ward PA. Requirements for tumor necrosis factor and interleukin-1 in limb ischemia/reperfusion injury and associated lung injury. Am J Pathol. 1993;143:453-63.

18. Lucchesi RR. Complement, neutrophils and free radicals mediators of reperfusion injury. Arzneimittelforschung. 1994;44:420-32.

19. Aslan A, Karaguzel G, Celik M, Uysal N, Yucel G, Melikoglu M. Pentoxifylline contributes to the hepatic cytoprotective process in rats undergoing hepatic ischemia and reperfusion injury. Eur Surg Res. 2001;33:285-90.

20. Iwamoto H, Kozaki N, Nakamura K, Hama K, Narumi N, Matsuno N, Kuzuoka K, Taira S, Kihara Y, Uchiyama M, Takeuchi H, Nagao $\mathrm{T}$. Beneficial effects of pentoxifylline and propentoxifylline on the warm ischemic injury of rat livers. Transplant Proc. 2002;34:26778.

21. Oliveira-Júnior IS, Maganhin CC, Carbonel AA, Monteiro CM, Cavassani SS, Oliveira-Filho RM. Effects of pentoxifylline on TNFalpha and lung histopathology in HCL-induced lung injury. Clinics. 2008;63:77-84.

22. Freire Cerqueira N, Hussni CA, Bonetti Yoshida W, Lopes Sequeira J, Padovani CR. Effects of pentoxifylline and n-acetylcysteine on injuries caused by ischemia and reperfusion of splanchnic organs in rats. Int Angiol. 2008;27:512-21.

23. Campos T, Deree J, Martins JO, Loomis WH, Shenvi E, Putnam JG, Coimbra R. Pentoxifylline attenuates pulmonary inflammation and neutrophil activation in experimental acute pancreatitis. Pancreas. 2008;37:42-9.

24. Oliveira-Júnior IS, Oliveira WR, Cavassani SS, Brunialti MK, Salomao R. Effects of pentoxifylline on inflammation and lung dysfunction in ventilated septic animals. J Trauma. 2010;68:822-6.

25. Cavriani G, Domingos HV, Soares AL, Trezena AG, LigeiroOliveira AP, Oliveira-Filho RM, Sudo-Hayashi LS, Tavares de Lima W. Lymphatic system as a path underlying the spread of lung and gut injury after intestinal ischemia/reperfusion in rats. Shock. 2005;23:330-6.

26. Hammerman C, Goldschmidt D, Caplan MS, Kaplan M, Schimmel MS, Eidelman AI, Branski D, Hochman A. Amelioration of ischemia-reperfusion injury in rat intestine by pentoxifyllinemediated inhibition of xanthine oxidase. J Pediatr Gastroenterol Nutr. 1999;29:69-74.

27. Lowry $\mathrm{OH}$, Rosebrough NJ, Farr AL, Randall RJ. Protein measurement with the Folin phenol reagent. J Biol Chem. 1951;193:265-75.

28. Ohkawa H, Ohishi N, Yagi K. Assay for lipid peroxides in animal tissues by thiobarbituric acid reaction. Anal Biochem. 1979;95:3518.

29. Chu SJ, Perng WC, Hung CM, Chang DM, Lin SH, Huang KL. Effects of various body temperatures after lipopolysaccharideinduced lung injury in rats. Chest. 2005;128:327-36.

30. de Perrot M, Liu M, Waddell TK, Keshavjee S. Ischemia-reperfusioninduced lung injury. Am J Respir Crit Care Med. 2003;167:490-511.

31. Granger DN. Role of xanthine oxidase and granulocytes in ischemia-reperfusion injury. Am J Physiol Heart Circ Physiol. 1988;255:H1269-75.

32. Adkins WK, Taylor AE. Role of xanthine oxidase and neutrophils in ischemia-reperfusion injury in rabbit lung. J Appl Physiol. 1990;69:2012-8.

33. Sener G, Akgün U, Satiroğlu H, Topaloğlu U, Keyer-Uysal M. The effect of pentoxifylline on intestinal ischemia/reperfusion injury. Fundam Clin Pharmacol. 2001;15:19-22.

34. Pascher A, Klupp J. Biologics in the treatment of transplant rejection and ischemia/reperfusion injury: New applications for TNFa inhibitors? BioDrugs. 2005;19:211-31. 
35. Esposito E, Cuzzocrea S. TNF-alpha as a therapeutic target in inflammatory diseases, ischemia-reperfusion injury and trauma. Curr Med Chem. 2009;16:3152-67.

36. Cámara-Lemarroy CR, Guzmán-de la Garza FJ, Alarcón-Galván G, Cordero-Pérez P, Muñoz-Espinosa LE, Fernández-Garza NE. Effects of thalidomide and pentoxyphylline over local and remote organ injury after intestinal ischemia/reperfusion. Transplant Proc. 2010;42:1624-6.

37. Strieter RM, Remick DG, Ward PA, Spengler RN, Lynch III JP, Larrick J, Kunkel SL. Cellular and molecular regulation of tumor necrosis factor-alpha production by pentoxifylline. Biochem Biophys Res Com. 1988;155:1230-6.

38. Orfanos SE, Mavrommati I, Korovesi I, Roussos C. Pulmonary endothelium in acute lung injury: from basic science to the critically ill. Intensive Care Med. 2004;30:1702-14.

39. Puneet $\mathrm{P}$, Moochhala S, Bhatia M. Chemokines in acute respiratory distress syndrome. Am J Physiol Lung Cell Mol Physiol. 2005;288:L3-15.

\section{Correspondence:}

Itamar Souza de Oliveira-Júnior

Disciplina de Anestesiologia, Dor e Terapia Intensiva-UNIFESP

Rua Napoleão de Barros, 715/ 5 andar

04024-002 São Paulo - SP Brazil

Tel/Fax: (55 11)5571-2746

ijuniors@hotmail.com

Received: May 11, 2011

Review: July 12, 2011

Accepted: August 15, 2011

Conflict of interest: none

Financial source: FAPESP

${ }^{1}$ Research performed at Department of Surgery, Department of Morphology and Genetics, Federal University of Sao Paulo

(UNIFESP), Brazil. Part of PhD degree thesis. Mentor: Itamar Souza Oliveira-Júnior. 